\title{
Sephadex Gel Filtration of $\gamma$-Glutamyl-Transpeptidase, Alkaline Phosphatase and Leucine Aminopeptidase in the Serum of Patients Affected by Various Liver Diseases
}

\author{
By G. IDÉo and G. RONCHI \\ Institute of Medical Patbology, University of Milan, Italy \\ "Antonio Migliavacca" Center for Liver Diseases
}

(Eingegangen am 26. November 1971)

\begin{abstract}
$\gamma$-Glutamyltranspeptidase, alkaline phosphatase and leucine aminopeptidase activities in the se:a of patients affected by various liver diseases were identified after gel filtration on Sephadex G 200.

Protein was scanned at $280 \mathrm{~nm}$ and the $19 \mathrm{~S}, 7 \mathrm{~S}$ and $4 \mathrm{~S}$ peaks obtained were used as points of reference.

Only one peak of $\gamma$-glutamyltranspeptidase activity, at the level of the $19 \mathrm{~S}$ protein fraction, was found in the sera of all patients studied.

Alkaline phosphatase and leucine aminopeptidase activity was divided into two peaks corresponding to the 19 and $7 \mathrm{~S}$ protein fractions. In cholestasis cases, whatever the pathology, alkaline phosphatase and leucine aminopeptidase activity present in the $19 \mathrm{~S}$ fraction were always more than $20 \%$ of the total activity, often reaching values above $40 \%$ of the total.
\end{abstract}

Im Serum von Patienten mit verschiedenen Lebererkrankungen wurden die Aktivitäten der $\gamma$-Glutamyltranspeptidase, alkalischen Phosphatase und Leucin-Aminopeptidase nach Gelfiltration an Sephadex G 200 untersucht.

Proteine wurden bei $280 \mathrm{~nm}$ gemessen und die $19 \mathrm{~S}-, 7 \mathrm{~S}$ - und $4 \mathrm{~S}$ Peaks als Bezugspunkte verwendet.

Im Serum aller untersuchten Patienten wurde nur ein Aktivitäts-Peak der $\gamma$-Glutamyltranspeptidase im Bereich der 19 S-Fraktion gefunden.

Die Aktivitäten der alkalischen Phosphatase und Leucin-Aminopeptidase verteilten sich auf zwei Peaks, die den 19 S- und 7 S-Fraktionen zugehörten. In Fällen von Cholostase jeglicher Ätiologie betrugen die Aktivitäten von alkalischer Phosphatase und Leucin-Aminopeptidase in der 19 S-Fraktion stets mehr als $20 \%$ und erreichten oft Werte über $40 \%$ der Gesamtaktivität.

Although many workers, using different methods, have proved the presence of $\gamma$-glutamyltranspeptidase (EC 2.3.2.1), alkaline phosphatase (EC 3.1.3.1) and leucine aminopeptidase (EC 3.4.1.1) isoenzymes in the serum in various disease states, the results are not in agreement and generally are not of sufficient clarity for application to clinical work. This paper reports data concerning the estimation of these isoenzymes by means of gel filtration on Sephadex G 200 in the serum of patients with various liver diseases.

Previous chromatographic estimations of $\gamma$-glutamyltranspeptidase by means of gel filtration have been entirely contradictory. ORLowsKI and SzCzEKLIK (1) found three peaks of enzyme activity: each peak was eluted with one of the three proteic fractions: the highest $\gamma$-glutamyltranspeptidase activity was eluted with albumin. Kокот and KUSKA (2), JACYSZYN and LAURSEN (3) also found three peaks: they reported that the highest one was eluted with the $19 \mathrm{~S}$ fraction. As far as the other two peaks are concerned, Кокот and KUSKA found them in the second protein fraction, while the other workers found them before the first fraction.

Only a few data are available about the gel filtration of alkaline phosphatase activity on Sephadex G 200. In normal serum a fraction of alkaline phosphatase activity at the level of the second peak eluted from the gel has been reported (4): in about 30\% of the cases a zone of activity (about $5 \%$ of the total activity) has been noted at the level of first peak.
In disease, two fractions are always observed: DUNNE and coworkers (5) showed that the first fraction is about $2 \%$ of the total activity in non-neoplastic bony diseases, $10 \%$ in neoplastic bony diseases, $12 \%$ in nonneoplastic liver diseases and $32 \%$ in metastatic liver tumours. According to these authors, therefore, the high concentration of alkaline phosphatase activity present in the first fraction is characteristic of metastatic tumours. Recently JenNINGs and coworkers (6) seem to have confirmed these results.

\section{Material and methods}

\section{Sephadex gel filtration}

We performed gel filtration on Sephadex G 200 (PharmaciaUpsala, Sweden). Column size was $45 \times 2.5$ according to Frodis and Krllander's method (7). Two $\mathrm{ml}$ of serum were applied to the column for each chromatographic estimation. Tris buffer $0.1 \mathrm{M}$ $\mathrm{pH} 8.1+\mathrm{NaCl} 0.5 \mathrm{~m}$ was used for the elution.

Protein concentration was measured at $280 \mathrm{~nm}$ by a Uvicord Automatic Ultraviolet Absorption Detector. The eluate was collected automatically in $3 \mathrm{ml}$ fractions.

\section{Determination of $\gamma$-glutany'ltranspeptidase}

We determined the $\gamma$-glutamyltranspeptidase activity by the method of SzAsz (8), using $L-\gamma$-glutamyl-p-nitroanilide as substratc.

\section{Deternination of alkaline pibosplsatase}

Alkaline phosphatase activity was determined by the kinetic test at $25^{\circ}$ and a wave length of $405 \mathrm{~nm}$, the substrate being $p$-nitrophenylphosphate (9). 
As we used a $\mathrm{pH} 8.1$ buffer for gel filtration, it was necessary to correct the $\mathrm{pH}$ of the mixture in the cuvette to $\mathrm{pH} 10.5$ with $\mathrm{NaOH}$, because this $\mathrm{pH}$ is required for the maximum activity of alkaline phosphatase.

\section{Determination of leucine aminopeptidase}

Leucine aminopeptidase activity, was also determined by the kinetic test at $25^{\circ}$ and a wave length of $405 \mathrm{~nm}$. This method utilizes as substrate I-leucyl-p-nitroanilide (10).

The case material included 8 patients with acute hepatitis, 7 with chronic hepatitis, 8 with portal cirrhosis, 21 with cholestasis ( 1 with cancer of the head of the pancreas, 1 with cancer of choledochus, 4 with choledocholithiasis, 7 with primary or metastatic liver neoplasms, 1 with cholestasis in HoDGKIN disease, 3. with cholangitis, 3 with primary or secondary biliary cirrhosis and 1 with drug cholestasis).

The diagnosis was based upon clinical, biochemical and, in most cases, histological or peritoneoscopic criteria.

In some of these cases, after gel filtration of serum, only one or two enzymes were estimated.

In our laboratories normal values for $\gamma$-glutamyltranspeptidase are $8-28 \mathrm{U} / \mathrm{l}$ of serum, for alkaline phosphatase $12-30 \mathrm{U} / \mathrm{l}$ of serum and for leucine aminopeptidase $8-22 \mathrm{U} / 1$ of serum.

\section{Results}

Figure 1 shows as a standard the protein profile of normal serum, submitted to gel filtration on a Se-
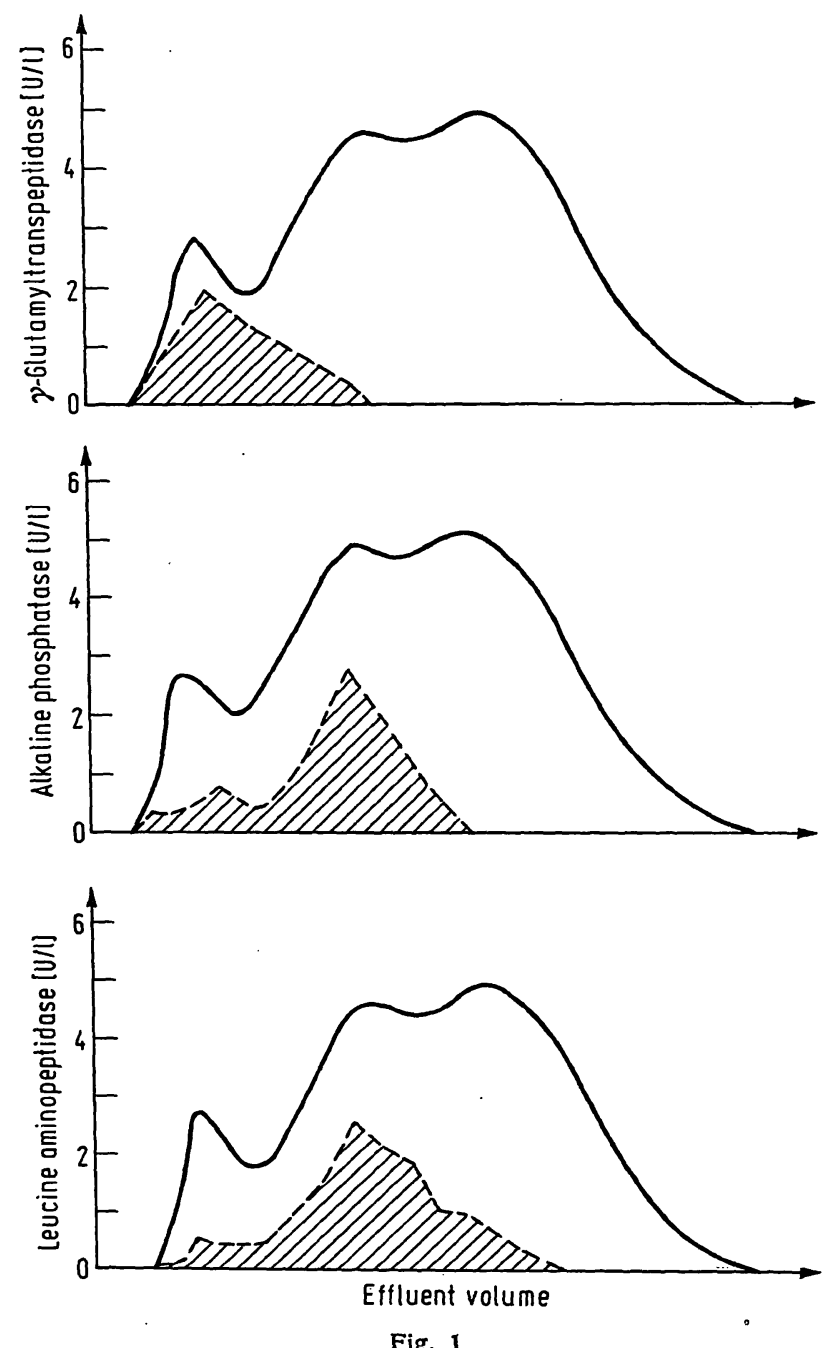

Gel filtration patterns of sera from normal subjects. Shaded areas: activity of $\gamma$-glutamyltranspeptidase, aikaline phosphatase and leucine aminopeptidase phadex G 200 column. The proteins are eluted in three main peaks corresponding to the $19 \mathrm{~S}, 7 \mathrm{~S}$ and $4 \mathrm{~S}$ (and albumin) fractions, as defined by ultracentrifugation (7). $\gamma$-Glutamyl transpeptidase activity appears only in the first eluted protein fraction. Alkaline phosphatase and leucine aminopeptidase are present either in the first or in the second eluted protein fraction: but the activity is mainly located in the second fraction, because the first fraction levels never exceed $10 \%$ 'of the total activity.

Tables 1, 2 and 3 show the distribution of $\boldsymbol{\gamma}$-glutamyltranspeptidase, alkaline phosphatase and leucine aminopeptidase in the three eluted protein fractions in the morbid forms we considered. It is evident that $\gamma$ glutamyltranspeptidase is always present only in the first fraction eluted from the gel, and it shows no difference between any of the liver diseases.

Alkaline phosphatase activity, on the other hand, shows variations: in acute hepatitis, chronic hepatitis and cirrhosis, the activity which appears in the first eluted fraction is quite small - often indeterminate - and

Tab. 1

Gel filtration pattern of $y$-glutamyltranspeptidase in serum of patients with various liver diseases. $7 \mathrm{~S}$ peak and $4 \mathrm{~S}$ peak were absent

\begin{tabular}{rlrc}
\hline $\begin{array}{c}\text { Case } \\
\text { No. }\end{array}$ & \multicolumn{1}{c}{ Diagnosis } & $\begin{array}{c}\text { Total } \\
\text { activity } \\
\text { U/l of serum }\end{array}$ & $\begin{array}{c}\% \text { en- } \\
\text { zyme di- } \\
\text { stribution } \\
19 \text { S peak }\end{array}$ \\
\hline 1 & Infective hepatitis & 85 & 100 \\
2 & Infective hepatitis & 17 & 100 \\
3 & Infective hepatitis & 80 & 100 \\
4 & Infective hepatitis & 180 & 100 \\
5 & Chronic hepatitis & 27 & 100 \\
6 & Chronic hepatitis & 65 & 100 \\
7 & Chronic hepatitis & 140 & 100 \\
8 & Portal cirrhosis & 111 & 100 \\
9 & Portal cirrhosis & 858 & 100 \\
10 & Drug cholestasis & 388 & 100 \\
11 & Cholangitis & 210 & 100 \\
12 & Cholangitis & 290 & 100 \\
13 & Benign obstruction (stone) & 840 & 100 \\
14 & Primary biliary cirrhosis & 611 & 100 \\
15 & Primary biliary cirrhosis & 122 & 100 \\
16 & Secondary biliary cirrhosis & 155 & 100 \\
17 & Malignant hepatoma & 420 & 100 \\
18 & Malignant hepatoma & 275 & 100 \\
19 & Secondary carcinoma liver & 450 & 100 \\
20 & Secondary carcinoma liver & & \\
21 & Secondary carcinoma liver & & \\
\hline
\end{tabular}

Tabl. 2.

Gel filtration pattern of alkaline phosphatase in serum of patients with various liver diseases. $4 \mathrm{~S}$ peak were absent

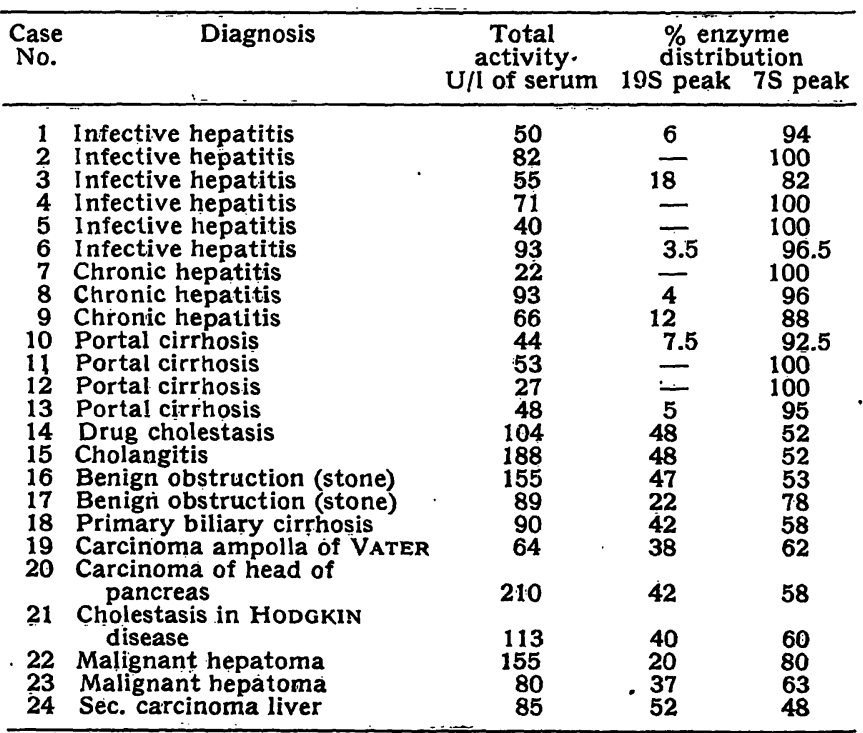

Z. klin.' Chem. u. klin. Bioçhem./ 10. Jahrg. 1972/ Heft'5 


\section{Ihm kann „keener'...}

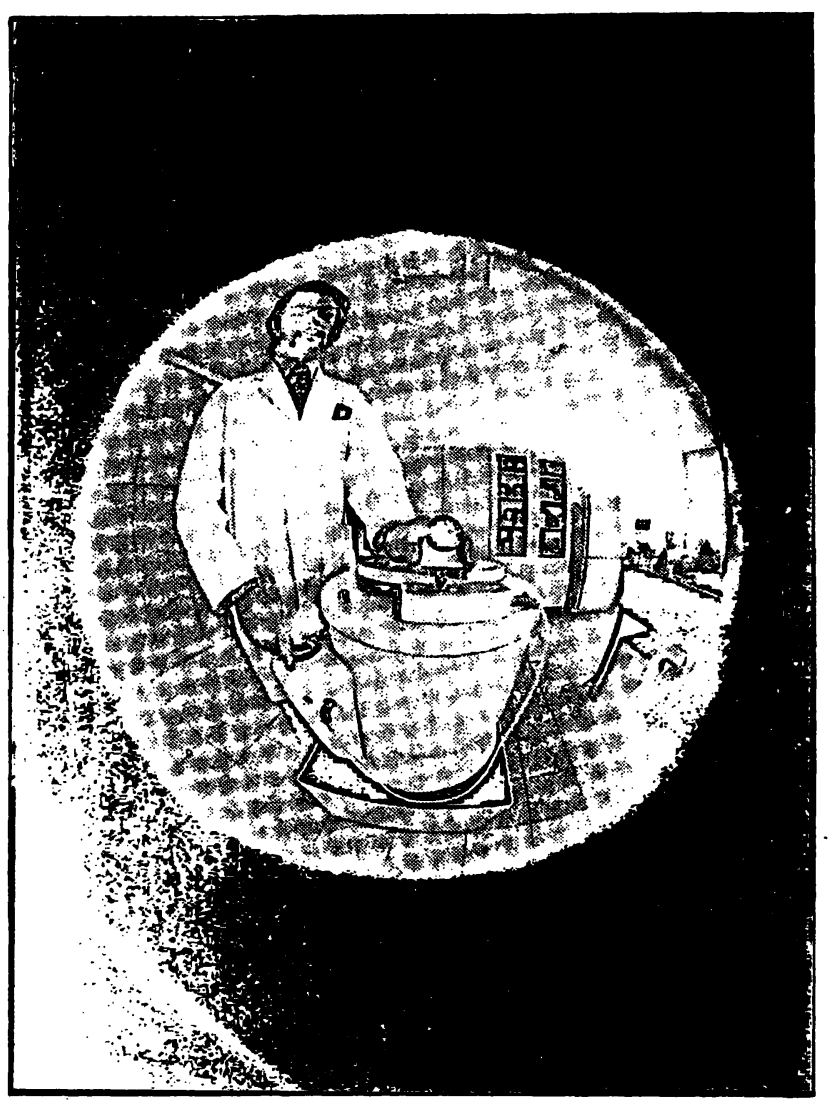

... auch kein Prüfer der Berufsgenossenschaft. Seine UNIVERSAL JUNIOR II hat die UVV*-gemäße Deckelverriegelung und -zuhaltung, wie alle Heraeus-Christ-Zentrifugen mit Antriebsleistungen über 500 Watt.

\section{Er weiß nämlich:}

wer mit Zentrifugen ab 500 Watt arbeitet, die keine Deckelverriegelung haben, kann sehr hoch bestraft werden. Bis zu 10.000,- DM kann das kosten.

\section{Teure Sache!}

Heraeus-Christ-Zentrifugen kommen am Ende billiger. Unzählige Laborfachleute arbeiten bereits Jahizehnte damit. Sie wissen: was bei Heraeus-Christ konstruiert und gebaut wird, ist unübertroffen in Leistung und Perfektion.

Verlangen Sie bitte ausführliche Unterlagen unter Kennziffer

- Unfallverhütungsvorschrift für Schleudermaschinen (VBG 7 z) gültig ab 1. 10. 1971

\section{HERAEUS-CHRIST GMBH} 3360 OSTERODE - Postfach 1220

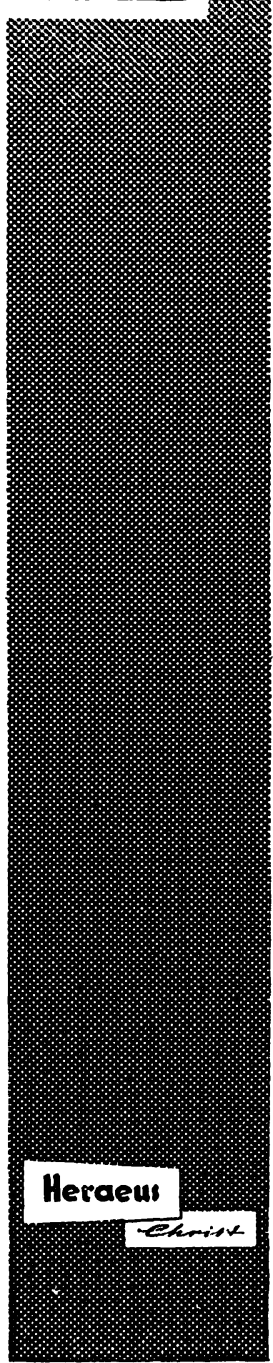

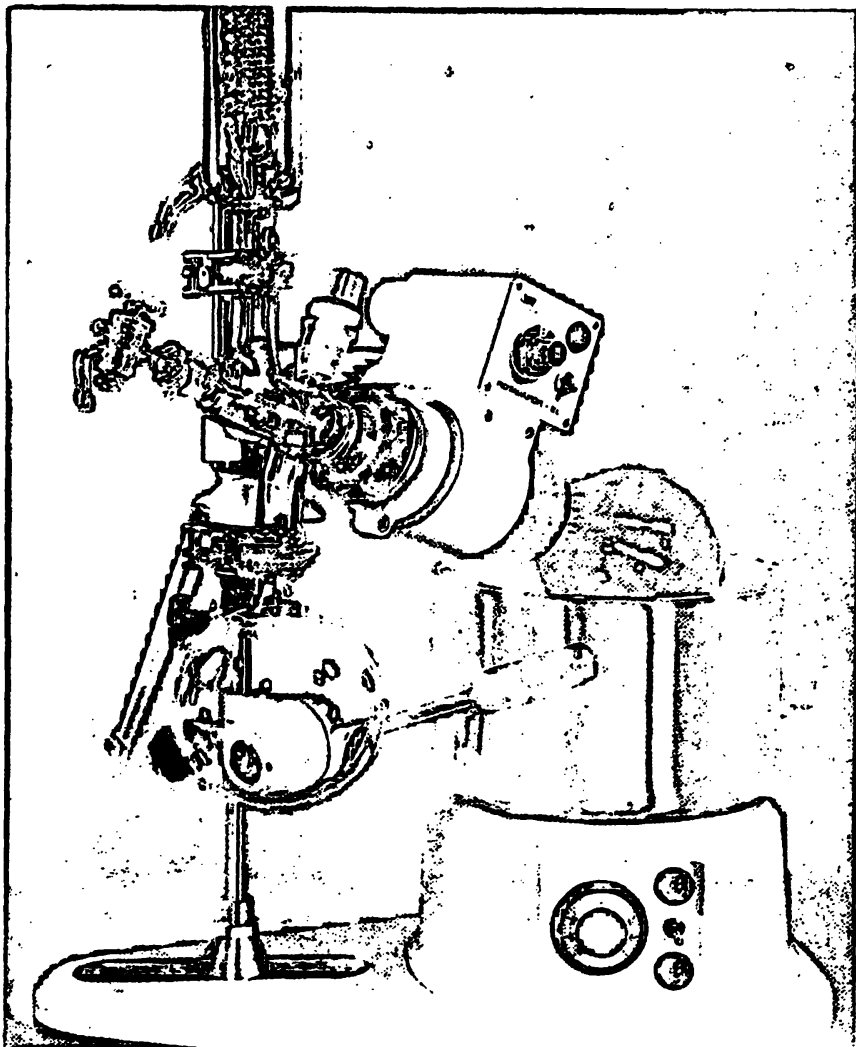

\section{Büchi-}

\section{Rotavapor EL Standard}

International bewährter Rotationsverdampfer der bekannten Rotavapor-Baureihe der Firma W. Büchi, Flawil (Schweiz). Elektronisch gesteuerte und stufenlos einstellbare Drehzahl mit konstantem Drehmoment im gesamten Bereich von 10 bis $220 \mathrm{U} / \mathrm{min}$ (auch bei voller Belastung). Patentierte Dampfdurchführung ohne bewegteTeile,

\section{Alleinvertretung für Deutschland: \\ Colora Messtechnik GmbH 7073 Lorch/Württ., Postfach 5 T(07172) 6041, FS 07-248886}

Technische Büros (Verkauf und Kundendienst): 1000 Berlin 30, Kurfürstenstraße 84, T 2615200 2000 Hamburg 19, Osterstraße 63, T 4911034 , FS 02-12 947 3000 Hannover, An der Tiefenriede 45, T 884500 4000 Düsseldorf, Kronprinzenstr. 62, T 3201 64, FS 08-587 253 6000 Frankfurt a.M., Röderbergweg 4-6, T446031, FS 04-11 216 8000 München 19, Dachauer Straße 175, T 193858

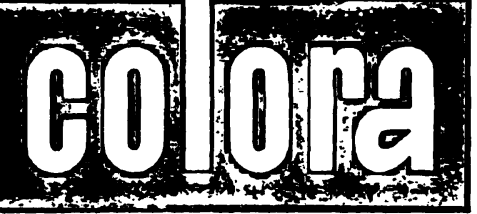




\section{Walter de Gruyter Berlin-New York}

$\cdot 1$

\section{H. Rainer Maurer}

\section{Disc Electrophoresis}

and Related Techniques of Polyacrylamide Gel Electrophoresis

Second revised and expanded edition. Octavo. XVI, 222 pages. With 88 figures, 16 tables and 948 literature references. 1971.

Bound DM 68, -; \$ 21.75

ISBN 3110034956

(Working Methods in Modern Science. Edited by Prof. Dr. Kurt Fischbeck)

This updated and revised monograph in English language brings together - as far as possible - the body of widely dispersed knowledge and experience obtained from methods in disc electrophoresis and related techniques of polyacrylamide gel electrophoresis. The book is intended to be a laboratory manual with the purpose of sparing the user time consuming literature study and technical errors as much as possible. Included are exact procedures for the most varied separation problems, a survey of types of apparatus, descriptions of methods for detection and quantitation of proteins, nucleic acids, enzymes, antigens and radioactivities, a detailed treatment of micro disc electrophoresis, preparative polyacrylamide gel electrophoresis and many other techniques for special problems. In addition, this monograph also cites examples of results from research in biochemistry, clinical chemistry and food technology with the infention of offering suggestions and showing the versatility of the method. From the information in this book, the user should be able, without any previous experience, to solve his separation problems to his (her) satisfaction.
Weiterhin lieferbar:

\section{Maurer}

Disk-Elektrophorese

Theorie und Praxis der

diskontinuierlichen Polyacrylamidgel-

Elektrophorese. Mit einem Geleitwort von

E. Hecker. Okfav. Mit 82 Abb., 15 Tab.,

1 Ausschlagtaf., 578 Liferaturangaben.

XVI, 221 S. 1968. Gebunden DM 36, -

(Arbeitsmethoden der modernen

Naturwissenschaften, herausgegeben von Prof. Dr. Kurt Fischbeck)

\section{Helmut A. Fischer \\ Gottfried Werner}

\section{Autoradiography}

Octavo: $X, 198$ pages. With 93 figures and 1.4 tables. 1971.

Bound DM 64, -; \$20.50

ISBN 3110035235

(Working Methods in Modern Science. Edited by Prof. Dr. Kurt Fischbeck)

"Autoradiography" describes the methods and techniques, possibilities and limitations of the qualitative and quantitative autoradiography of macroscopic, microscopic and electron-microscopic specimens. The book is of interest to all those working with radio-isotopes in scientific and medical fields and to all scientific and technical libraries, institutes, clinics and all laboratories of scientific subjects.

Weiterhin lieferbar:

Fischer-Werner

Autoradiographie

Mit 93 Abb. U. 14 Tab. Oktav. X, 214 S.

1971. Geb. DM 42, -

ISBN 3110064049

(Arbeitsmethoden der modernen

Naturwissenschaffen, herausgegeben von Prof. Dr. Kurt Fischbeck) 
Tab. 3

Gel filtration pattern of leucine aminopeptldase in serum of patients with various liver diseases. 45 peak were absent

\begin{tabular}{|c|c|c|c|c|}
\hline $\begin{array}{l}\text { Case } \\
\text { No. }\end{array}$ & Diagnosis & $\begin{array}{c}\text { Total } \\
\text { activity } \\
\text { U/l of serum }\end{array}$ & $\begin{array}{l}\% \text { enzy } \\
\text { distribut } \\
19 S \text { peak }\end{array}$ & $\begin{array}{l}y m e \\
\text { ion } \\
7 S \text { peak }\end{array}$ \\
\hline $\begin{array}{r}1 \\
2 \\
3 \\
4 \\
5 \\
6 \\
7 \\
8 \\
9 \\
10 \\
11 \\
12 \\
13 \\
14 \\
15 \\
16 \\
17 \\
18 \\
19 \\
20 \\
21\end{array}$ & $\begin{array}{l}\text { Infective hepatitis } \\
\text { Infective hepa titis } \\
\text { Infective hepatitis } \\
\text { Chronic hepatitis } \\
\text { Chronic hepatitis } \\
\text { Chronic hepatitis } \\
\text { Chronic hepatitis } \\
\text { Chronic hepatitis } \\
\text { Portal cirrhosis } \\
\text { Portal cirrhosis } \\
\text { Portal cirrhosis } \\
\text { Portal cirrhosis } \\
\text { Portal cirrhosis } \\
\text { Portal cirrhosis } \\
\text { Drug cholestasis } \\
\text { Cholangitis } \\
\text { Benign obstruction (stone) } \\
\text { Benign obstruction (stone) } \\
\text { Primary biliary cirrhosis } \\
\text { Carcinoma ampolla of VATER } \\
\text { Malignant hepatoma }\end{array}$ & $\begin{array}{r}30 \\
38 \\
45 \\
24 \\
55 \\
18 \\
16 \\
36 \\
24 \\
46 \\
48 \\
52 \\
35 \\
31 \\
68 \\
80 \\
54 \\
110 \\
46 \\
115 \\
55\end{array}$ & $\begin{array}{r}5 \\
12 \\
4 \\
18 \\
9 \\
20 \\
8 \\
26 \\
27 \\
12 \\
31 \\
28 \\
25 \\
11 \\
47 \\
52 \\
52 \\
19 \\
60 \\
39 \\
60\end{array}$ & $\begin{array}{l}95 \\
88 \\
96 \\
82 \\
91 \\
80 \\
92 \\
74 \\
73 \\
88 \\
69 \\
72 \\
75 \\
89 \\
53 \\
48 \\
48 \\
81 \\
40 \\
61 \\
40\end{array}$ \\
\hline
\end{tabular}
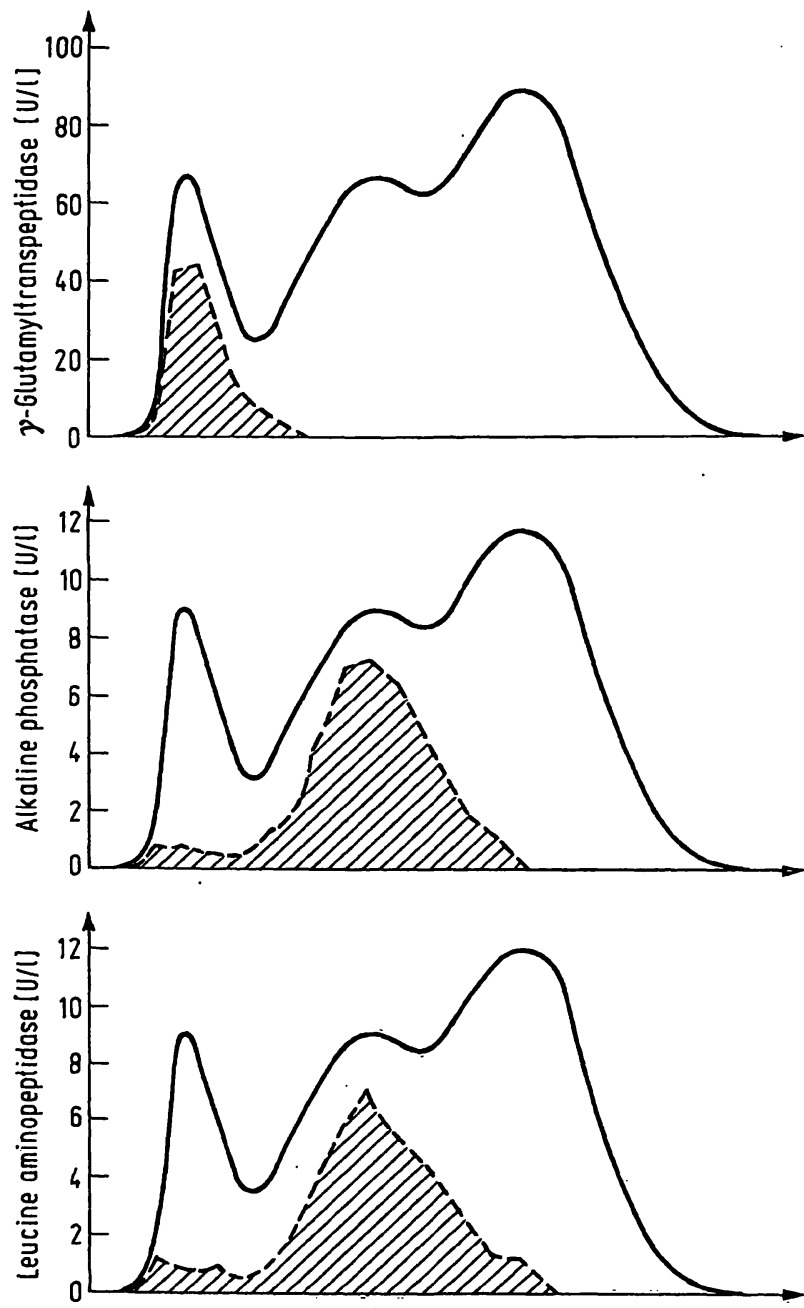

Effluent volume

Fig. 2

Gel filtration patterns of sera from patients with acute hepatitis. Shaded areas: activity of $\gamma$-glutamyltranspeptidase, alkaline phosphatase and leucine aminopeptidase

always less than $18 \%$ of the total activity. In cholestasis, whatever the cause, alkaline phosphatase activity present in the first fraction is always more than $20 \%$ of the total, very often reaching values above $40 \%$.
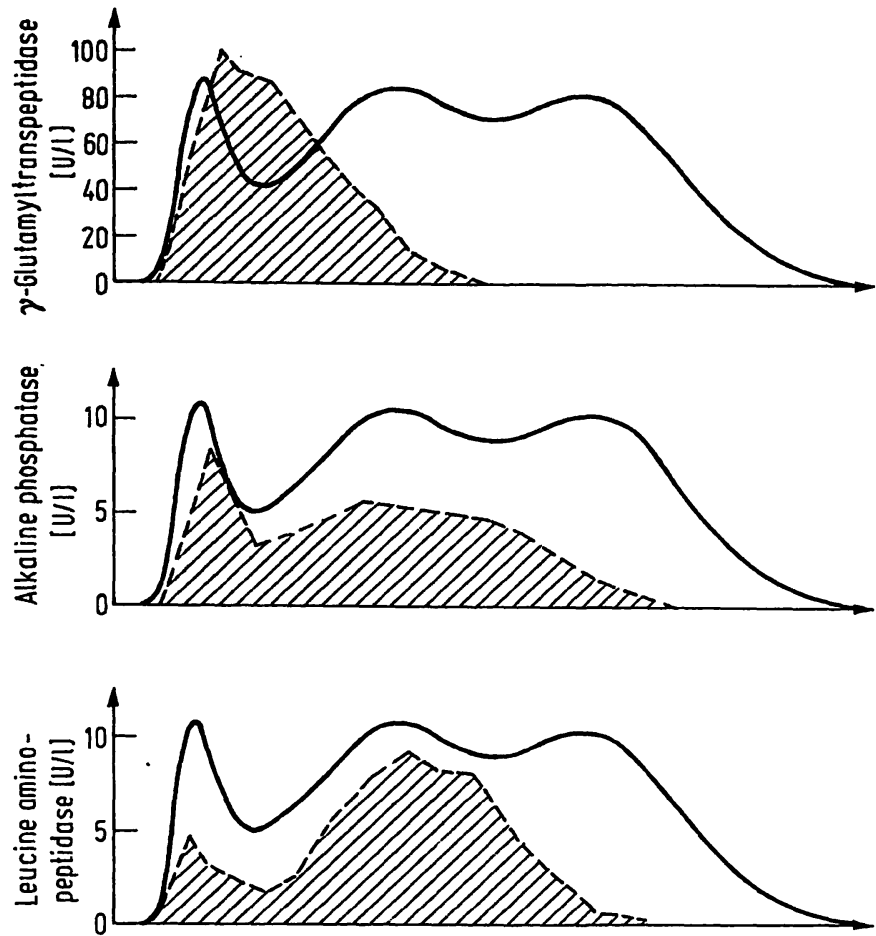

Effluent volume

Fig. 3

Gel filtration patterns of sera from patients with cholestatic jaundice Shaded areas: activity of $\gamma$-glutamyltranspeptidase, alkaline phosphatase and leucine aminopeptidase

Leucine aminopeptidase activity appears to behave in a similar fashion. The percentage of leucine aminopepitdase activity present in the first protein peak eluted by gel is quite high in cholestasis. A notable increase of the first fraction was seen even in the cirrhosis cases (values of about $25-30 \%$ ).

Figures 2 and 3 show as a standard the protein profiles and related zones of activity of $\gamma$-glutamyltranspeptidase, alkaline phosphatase and leucine aminopeptidase in patients affected respectively by acute hepatitis and cholestasis.

\section{Discussion}

Only one peak of $\gamma$-glutamyltranspeptidase activity was found in the sera of all cases studied by gel filtration on Sephadex G 200. This peak was eluted together with the first protein fraction. Therefore $\gamma$-glutamyltranspeptidase seems to be a rather homogeneous enzyme with molecular weight about 200,000 . However some little differences in molecular weight can be shown when the eluted fractions with $\gamma$-glutamyltranspeptidase activities are again characterized by means of gel filtration (11). The different results of other authors might be explained by the formation of multiple molecular forms as speculated by ORLOwsKI and SzCzenIIK (1) or by the different methods in enzyme assay. It might also be that colorimetric methods used to test $\gamma$-glutamyltranspeptidase levels detect non-specific enzyme activities. Otherwise it is difficult to see how LAURSEN and coworkers (3) found $\gamma$-glutamyltranspeptidase activity peaks which were eluted even earlier than the heaviest protein fraction. 
The detection on Sephadex G 200 of the serial alkaline phosphatase activity showed a characteristic pattern in the sera of patients suffering from cholestasis. In fact only in these patients was it possible to find a high level of alkaline phosphatase activity present in the first eluted fraction. DUNNE and coworkers (5) and JENNINGS and coworkers (6) asserted that this pattern was specific for the serum of patients with primary or metastatic liver tumours: but DuNNE and coworkers have not studied the sera of patients suffering from other forms of cholestasis; and of only two patients affected by benign obstruction considered by JENNINGS and coworkers, one showed high alkaline phosphatase activity ( $31 \%$ of total) in the first fraction. We therefore believe that the presence of a high level at the first peak is found in all cases of cholestasis, whatever the cause.

NEwTON and coworkers (12) and DUNNE and corworkers (5) suggest that this alkaline phosphatase activity related to $19 \mathrm{~S}$ fraction could be a lipoprotein complex. The re- sults of JENNINGs and coworkers (6) seem to support this view. These authors observed that, after $\mathrm{n}$-butanol extraction of conceritrated 19 S column eluents, alkaline phosphatase activity moved to the $7 \mathrm{~S}$ position. On the other hand, an increase in lipoproteins has also been observed in obstructive jaundice $(13,14)$. However, since in some cases JeNNINGs and coworkers observed a considerable loss of alkaline phosphatase activity after n-butanol extraction, we cannot exclude the possibility that alkaline phosphatase activity related to the $19 \mathrm{~S}$ fraction may partly be an enzyme polymer (5).

As far as the leucine aminopeptidase activity is concerned, we have observed the presence of two peaks after serum gel filtration, eluting at the level of $19 \mathrm{~S}$ and $7 \mathrm{~S}$ protein fractions respectively. The changes of the percentages of these two peaks in different liver diseases are similar to the changes in alkaline phosphatase: so the deductions made about alkaline phosphatase activity apply equally to leucine aminopeptidase.

\section{References}

1. Orlowski, M. and A. Szczekrik, Clin. Chim. Acta, Amsterdam 15, 387 (1967). - 2. Kokot, F. and J. Kuska, Enzymol. biol. Clin. 9, 59 (1968). - 3. JaCyszYN, K. and T. Laursen, Clin. Chim. Acta, Amsterdam 19, 345 (1968). - 4. Estrorn, B., this journal 2, 53 (1964). - 5. DunNe, J., J. J. FenNeLLY and K. McGeeney, Cancer 20, 71 (1967). - 6. Jennings, R. C., D. Brocklehurst and M. Hirst, Clin. Chim. Acta, Amsterdam 30, 509 (1970). - 7. Flodin, P. and J. KILLANDER, Biochim. biophysica Acta, Amsterdam 63, 403 (1962). - 8. Szasz, G. Clin.
Chem., N. Y. 15, 124 (1969). - 9. Hausamen, T. U., R. HelgeR, W. RICK, and W. Gross, Clin. Chim. Acta, Amsterdam 15, 241 (1967). - 10. Szasz, G., Amer. J. Clin. Pathol. 47, 607 (1967). 11. IdÉo, G., A. Morgantr, and N. Droguardi, Digestion, 5, 326 (1972). - 12. Newton, M. A., Quart. J. Med. 36, 17 (1967). 13. Phillips, G. B., J. Clin. Invest. 39, 1639 (1960). - 14. SerdeI, P., P. Alanmovick and R. H. Furman, J. Clin. Invest. 48, 1211 (1969).

Prof. Gaetano Idéo Corso di Porta Romana 106 I-20122 Milano 